\title{
Ecological Risk Assessment of Heavy Metals in Sediments from the Soubeira Reservoir, a Small-Scale Reservoir in North Central Burkina Faso, West Africa
}

\author{
Souleymane Pélédé ${ }^{1}$, Aboubakar Sako ${ }^{2}$ \& Ousmane Bamba ${ }^{1}$ \\ ${ }^{1}$ Université Ouaga 1 Pr Joseph Ki-Zerbo, Département des Sciences de la Terre, 09 BP 848 Ouagadougou 09, \\ Burkina Faso \\ ${ }^{2}$ Université de Dédougou, BP 139 Dédougou, Burkina Faso \\ Correspondence: Aboubakar Sako, Université de Dédougou, BP 139 Dédougou, Burkina Faso. E-mail: \\ aboubakar.sako@gmail.com
}

Received: February 28, $2018 \quad$ Accepted: March 19, $2018 \quad$ Online Published: March 30, 2018

doi:10.5539/ep.v7n1p66

URL: https://doi.org/10.5539/ep.v7n1p66

\begin{abstract}
Small-scale reservoirs play a central role in socio-economic development of Burkina Faso. In the absence of a best environmental management plan, these reservoirs can be potential factors of water pollution and ecological deterioration. In the present study, we investigated ecological status of sediments from the Soubeira reservoir, using concentrations of a series of heavy metals. Concentrations of the metals ranked as follows: $\mathrm{Fe}>\mathrm{Mn}>\mathrm{Cr}>$ $\mathrm{Zn}>\mathrm{Cu}>\mathrm{Pb}>\mathrm{As} \sim \mathrm{Co}>\mathrm{Hg} \sim \mathrm{Mo}>\mathrm{Cd}$. Based on the correlation analysis, $\mathrm{Fe}$, with weaker relationships with other metals, may be derived from the local ferruginous soil, whereas $\mathrm{Cd}, \mathrm{Cu}$ and $\mathrm{Cr}$ could be mainly originated from anthropogenic sources and carried by clay minerals into the reservoir. In contrast, $\mathrm{Hg}$ and As abundance could be related to artisanal gold mining in the surrounding environment. Negative correlations between heavy metals (except As) with $\mathrm{pH}$ were consistent with desorption and mobility of the majority of heavy metals under low $\mathrm{pH}$ values. The significant negative correlations were also observed between CEC and As $(\mathrm{r}=-0.75)$ and between clay and As $(r=-0.64)$. This could be an indication of As mobility under the physico-chemical conditions of the reservoir. Both potential ecological risk and adverse effect indices suggested that the reservoir sediments were highly polluted. Five heavy metals ( $\mathrm{As}, \mathrm{Cd}, \mathrm{Cu}, \mathrm{Cr}$ and $\mathrm{Hg}$ ) could cause adverse effect to biota, whilst only $\mathrm{Hg}$ and $\mathrm{Cd}$ appeared to show high and moderate potential ecological risk indices, respectively. The study demonstrated that the Soubeira reservoir requires a heavy metal pollution control program.
\end{abstract}

Keywords: small-scale reservoirs, sediment pollution, heavy metals, benthic organisms, physico-chemical parameters

\section{Introduction}

In Burkina Faso, the agricultural sector contributes about $40 \%$ to the Gross National Product and employs more than $80 \%$ of the workforce (INSD, 2011). In this semi-arid country, the rainfall regime is erratic and unevenly distributed with the northern region receiving less than $500 \mathrm{~mm}$ rainfall per year (Mahé and Paturel, 2009; Ibrahim et al., 2012). To meet the growing demands for freshwater, more than 1700 small- and medium-scale reservoirs were built across the country (Cecchi et al., 2009; Venot and Cecchi, 2011). Most of these reservoirs were constructed within the Nakambe River Basin (formerly White Volta) where population densities are high ( 100 inhabitants $/ \mathrm{km}^{2}$; INSD, 2000). These reservoirs have attracted many farmers and artisanal gold miners from distant villages, putting more pressure on water resources (Morin, 1990). Consequently, domestic wastewater, agricultural runoff and mining waste, rich in heavy metals (defined here as metallic and metalloid elements of density equal to or greater than $6 \mathrm{~g} / \mathrm{cm}^{3}$ ), are discharged into the adjacent reservoirs.

Because of their persistence in the aquatic environment and their accumulation in biota, heavy metals may enter foodweb and pose serious threats to human health (Nüremberg, 1984; Cook et al., 1990; Deniseger et al., 1990; Förstner, 1990; Harte et al., 1991). Some heavy metals such as $\mathrm{Zn}, \mathrm{Co}, \mathrm{Cu}, \mathrm{Cr}, \mathrm{Mo}, \mathrm{Fe}$ and $\mathrm{Mn}$ are involved in numerous biochemical processes in organisms, but can be toxic at high concentrations (Sandstead, 1995). In contrast, non-essential heavy metals (notably $\mathrm{As}, \mathrm{Pb}, \mathrm{Cd}$ and $\mathrm{Hg}$ ) may cause acute or chronic toxicity even at low concentrations (Muñoz-Olivas and Cámara, 2001; Kabata-Pendias, 2011). 
Once introduced into the aquatic environment, heavy metals are redistributed throughout the water column, adsorbed or accumulated in bottom sediments (Macklin et al., 2006; Martin, 2000; Nouri et al., 2008; Reza and Singh, 2010). Depending on the physico-chemical conditions such as mineralogical composition, $\mathrm{pH}$, cation exchange capacity (CEC) and the presence or absence of inorganic and organic ligands, previously adsorbed heavy metals onto sediments can be released back into the underlying water, making sediments a secondary source of water pollution (Calmano et al., 1990). Due to fluctuations in discharge and short water residence time, monitoring of pollutants in the water column alone is not conclusive (Förstner and Wittman, 1983). Moreover, in streams and rivers, reduced water velocity in some reaches may result in sediment accumulation in localized areas, whereas, in lakes and reservoirs, sediments are more uniformly distributed (Yi et al., 2011; Rosen, 2015). Thus, the impact of anthropogenic pollution on atmosphere, hydrosphere, biosphere and pedosphere is well preserved in lacustrine and reservoir sediments compared to those of streams and rivers (Mackay, 2001; Choi and Wania, 2011).

Several studies have investigated biological pollution and its health impacts related to small-scale reservoirs in Burkina Faso (e.g., Poda, 1996; Poda and Traoré, 2000; Cecchi et al., 2004; Leboulanger et al., 2008), but heavy metal contamination of these reservoirs has been generally ignored. Given the paucity of published data on heavy metal contamination of small reservoirs in semi-arid climatic zones, the objectives of the present paper are (1) to evaluate concentration levels of 11 heavy metals ( $\mathrm{As}, \mathrm{Cd}, \mathrm{Co}, \mathrm{Cr}, \mathrm{Cu}, \mathrm{Pb}, \mathrm{Fe}, \mathrm{Mn}, \mathrm{Mo}, \mathrm{Hg}$ and $\mathrm{Zn}$ ) in the Soubeira reservoir, (2) to identify the geogenic and anthropogenic sources of these metals in the reservoir, using correlation analysis and (3) to assess the degree of potential environmental risk and adverse biological effect of selected potentially harmful heavy metals (i.e., $\mathrm{As}, \mathrm{Cd}, \mathrm{Cr}, \mathrm{Cu}, \mathrm{Hg}, \mathrm{Pb}$ and $\mathrm{Zn}$ ), using potential ecological risk index (PERI) and adverse effect index (AEI). The findings of this study can be used to ascertain the suitability of a small-scale reservoir in semi-arid environmental settings for different water uses and to provide baseline data for an effective water quality monitoring program within a given watershed.

\subsection{Site Description and Environmental Setting}

The Soubeira reservoir is an earth-fill reservoir that was built in 1986 on the Nakambe River drainage basin in the north central Burkina Faso (Fig. 1). The reservoir is underlain by Birimian volcanic and volcano-sedimentary rocks (Hottin and Ouédraogo, 1972). With a storage capacity of $494000 \mathrm{~m}^{3}$ and a height of $3.70 \mathrm{~m}$, this small-scale reservoir is fed by numerous tributaries of the Nakambe River. The study area is situated in the Sudano-Sahelian climatic zone characterized by an extended dry season from November to May with an average annual rainfall of $751 \mathrm{~mm}$ (BUNASOL, 1990). The catchment of the Soubeira reservoir has an area of $110 \mathrm{~km}^{2}$ and it is mainly occupied by farmlands and perennial grassland (Fontes and Guinko, 1995). The predominant soil types in the area are ferruginous tropical soils (Boulet, 1968).

The main activities in this rural area are agriculture, animal husbandry and artisanal gold mining. As a result, water of the Soubeira reservoir is used for livestock watering and irrigation of off-season vegetable and crop growing, domestic water supply, brick making and ore processing. Although the reservoirs may have potentiality to significantly improve livelihood of the local population (Savy et al., 2006; Cecchi, 2007), their multifunctional use will inevitably deteriorate surface water quality (Vincent, 1994; Ersado, 2005; Boelee et al., 2009). 


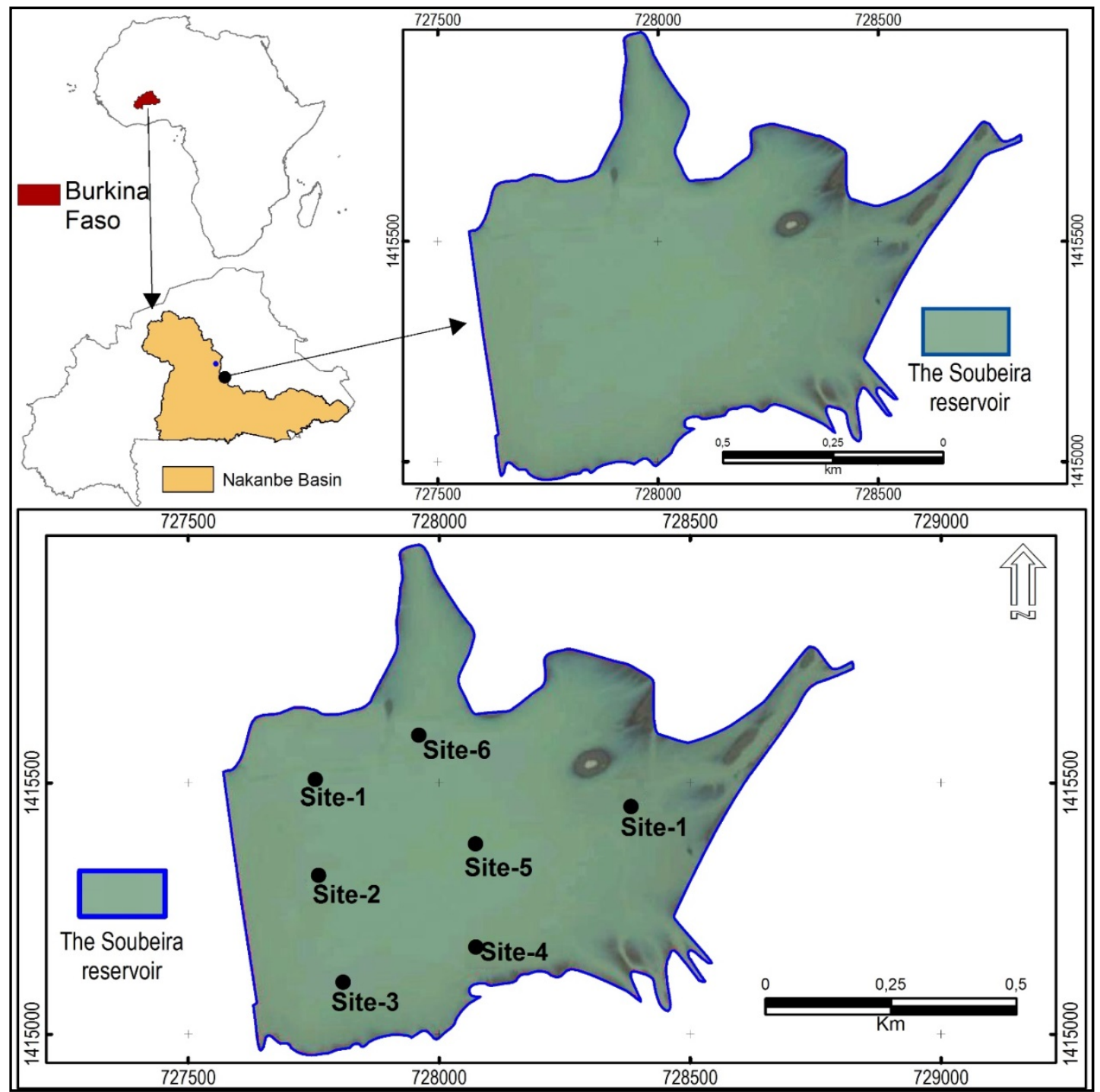

Figure 1. Map of Burkina Faso showing the Nakambe River Basin and the Soubeira reservoir with sampling sites

\section{Materials and Methods}

Core sediment samples were collected from seven sites within the reservoir using a hand-held stainless steel corer (Beecker 0.23. SA). Sites 7 and 6 are located in the reservoir intake and sites 1, 2 and 3 in the overflow discharge points, whereas sites 4 and 5 are located between inlet and discharge points (Fig. 1). The depth of sampled cores varied between 44 and $57 \mathrm{~cm}$. All samples were sealed in clean polyethylene bags and stored in an ice box. Once in the laboratory, cores were carefully mixed to form composite samples. The samples were subsequently air-dried at room temperature and sieved to remove coarse debris. A subset of each sample was used to determine granulometric composition, using physical separation method (Rouiller et al., 1994). A second subset was finely powdered in an agate mortar for chemical analysis. The $\mathrm{pH}$ values of the samples were measured in 1: $2.5 \mathrm{mgL}^{-1}$ sediment/water ratio, and total organic carbon contents (TOC) were quantified using the Walkey-Black wet digestion method (Nelson and Sommers, 1992). The Ag-Thiourea (AgTu) method was used to extract basic cations (Pleysier and Juo, 1980). Glycol-ethnol was used to remove soluble salts in $1 \mathrm{~g}$ air-dry $(<2 \mathrm{~mm})$ of each sediment sample. Subsequently, $50 \mathrm{~mL}$ of $\mathrm{AgTu}(0.01 \mathrm{M})$ solution was added to the soluble salt-free samples, shaken, centrifuged at $15 \mathrm{rpm}$ for $4 \mathrm{~h}$ and filtered through a $0.2 \mu \mathrm{m}$ nylon membrane. Extractable cations $\left(\mathrm{Ca}^{2+}, \mathrm{Mg}^{2+}, \mathrm{Na}^{+}\right.$and $\left.\mathrm{K}^{+}\right)$and exchangeable $\mathrm{Ag}^{+}$concentrations of the filtrates were measured by Flame Atomic Absorption Spectrophotometer (Perkin Elmer AA100). The unbuffered CEC of the sediments was assumed to be the total reactive site concentrations of the solids.

Total heavy metal concentrations were measured in a mixture of $\mathrm{HN}_{3}, \mathrm{HCl}$ and $\mathrm{HF}$ in the laboratories of the 
"Bureau des Mines et de la Géologie du Burkina" (BUMIGEB). A subsample ( $0.5 \mathrm{mg}$ ) of each sample was transferred into a Teflon container and $15 \mathrm{~mL}$ of ultrapure $\mathrm{HNO}_{3}, \mathrm{HCl}$ and $\mathrm{HF}$ were added it. The mixture was digested in a microwave (CEM Mars5) for $60 \mathrm{~min}$. The digested samples were diluted to $100 \mathrm{~mL}$ with double deionized water (Milli-Q water) and their heavy metal concentrations were analyzed using an inductively coupled plasma-mass spectrometer (ICP-MS, Perkin Elan 9000). The Blanks and the Laterite Ore (GBM397-1) standard were digested and analyzed according to the same protocol as for sediment samples in order to evaluate the accuracy of the digestion method. The analytical results obtained for GBM397-1 differed by less than 15\% from the certified values. The detection limits (LD) for Fe and $\mathrm{Mn}$ were 0.07 and $0.04 \mathrm{mg} / \mathrm{kg}$, respectively. In contrast, $\mathrm{LD}$ was $0.01 \mathrm{mg} / \mathrm{kg}$ for $\mathrm{As}, \mathrm{Cd}, \mathrm{Co}, \mathrm{Cu}, \mathrm{Hg}$ and $\mathrm{Zn}$ and $0.001 \mathrm{mg} / \mathrm{kg}$ for $\mathrm{Mo}$ and $\mathrm{Pb}$.

\section{Results and Discussion}

\subsection{Sediment Characteristics}

In aquatic environments, positively charged heavy metal ions tend to be associated with sediments through a set of geochemical processes such as adsorption onto aluminosilicate and oxyhydroxides minerals, co-precipitation with $\mathrm{Fe}$ and Mn-oxyhydroxides and complexation with organic and inorganic ligands (Bruder et al., 2002; Sutherland and Tack, 2002). Following changes in physico-chemical parameters (e.g., pH, organic matter and clay content), sediments may release the heavy metals into the water column. As a result, a heavy metal control and monitoring program of a surface water system should take into account distribution patterns of physico-chemical parameters in sediments.

In the present study, physico-chemical parameters such as $\mathrm{pH}$, clay, TOC and CEC were uniformly and normally distributed in the Soubeira reservoir $(\mathrm{CV}<50 \%$ and low skewsness values; Tables $1-2)$. Thus, the texture ranged from loam to clay, suggesting that the sediments are likely to have a great affinity for heavy metals (Zhang et al., 2014; Saeedi et al., 2013). However, the slightly acidic pH $(5.4-6.0)$, except site $3(\mathrm{pH}=8)$, indicates that the Soubeira sediments may have a low buffering capacity. Therefore, a small decrease in $\mathrm{pH}$ may lead to remobilization of previously sediment-adsorbed heavy metals into the adjacent water column, and thereby increasing the metal bioavailability and their ecological risk (Calmano, 1988; Calmano et al., 1993; Kelderman and Osman 2007).

Organic matter content constitutes and important property of sediments, as it controls heavy metal mobility within the aquatic system (Violante et al., 2010). Because of the semi-arid climatic conditions (low rainfall and high temperatures), which reduce the input of organic matter, TOC was generally low in the sediment samples, and it ranged from 0.3 to $1.3 \%$ with the maximum values measured in sediments from sites 4,5 and 7 (Tables 1 ). The sites 1, 3 and 6, with the highest contents of sand also exhibited relatively low CEC and TOC contents. The overall low CEC (5.3- $13.2 \mathrm{cmol}_{\mathrm{c}} / \mathrm{kg}$ ) suggests that kaolinite, according to McBride (1994), could be the dominant clay type in the Soubeira sediments. With little or no permanent negative charges, heavy metal adsorption on kaolinite is pH-dependent (McBride, 1994). Hence, a small variation in $\mathrm{pH}$ will result in adsorption/desorption of heavy metals onto the Soubeira reservoir sediments. It can be reasonably concluded that $\mathrm{pH}$ is unlikely to play an important role in the heavy metal immobilization in the Soubeira sediments. 
Table 1. Physico-chemical parameters and potentially toxic heavy metal concentrations in seven surface sediment samples collected in the Soubeira reservoir

\begin{tabular}{lllllllll}
\hline Parameter & Unit & Site-1 & Site-2 & Site-3 & Site-4 & Site-5 & Site-6 & Site-7 \\
\hline $\mathrm{pH}_{\mathrm{H} 2 \mathrm{O}}$ & - & 6.0 & 5.5 & 8.8 & 5.4 & 5.5 & 5.8 & 5.4 \\
$\mathrm{TOC}$ & $\%$ & 0.5 & 0.8 & 0.3 & 1.3 & 1.1 & 0.5 & 1.1 \\
$\mathrm{CEC}$ & $\mathrm{cmol}_{\mathrm{c}} \mathrm{kg}$ & 8.5 & 12.1 & 7.3 & 10.8 & 11.6 & 5.3 & 13.2 \\
$\mathrm{Clay}$ & $\%$ & 39.2 & 47.1 & 33.3 & 47.1 & 47.1 & 33.3 & 54.9 \\
$\mathrm{Silt}$ & $\%$ & 31.4 & 39.2 & 27.5 & 39.2 & 43.1 & 37.3 & 33.3 \\
$\mathrm{Sand}$ & $\%$ & 29.4 & 13.7 & 39.2 & 13.7 & 9.8 & 29.4 & 11.8 \\
$\mathrm{Texture}$ & & $\mathrm{ClLm}$ & $\mathrm{Cl}$ & $\mathrm{ClLm}$ & $\mathrm{Cl}$ & $\mathrm{Lm}$ & $\mathrm{ClLm}$ & $\mathrm{Cl}$ \\
$\mathrm{Fe}$ & $\mathrm{mg} / \mathrm{kg}$ & 22195 & 21192 & 22138 & 21659 & 24089 & 14620 & 29024 \\
$\mathrm{As}$ & $\mathrm{mg} / \mathrm{kg}$ & 12.4 & 10.1 & 11.0 & 11.3 & 16.6 & 10.9 & 12.1 \\
$\mathrm{Cd}$ & $\mathrm{mg} / \mathrm{kg}$ & 0.9 & 0.9 & 1.0 & 0.9 & 1.0 & 1.1 & 0.9 \\
$\mathrm{Co}$ & $\mathrm{mg} / \mathrm{kg}$ & 13.2 & 12.4 & 11.5 & 12.6 & 12.7 & 8.6 & 17.7 \\
$\mathrm{Cr}$ & $\mathrm{mg} / \mathrm{kg}$ & 63.2 & 70.6 & 71.8 & 72.4 & 76.6 & 54.2 & 68.8 \\
$\mathrm{Cu}$ & $\mathrm{mg} / \mathrm{kg}$ & 33.1 & 41.5 & 26.8 & 37.5 & 44.3 & 27.6 & 52.6 \\
$\mathrm{Hg}$ & $\mathrm{mg} / \mathrm{kg}$ & 2.4 & 2.6 & 1.4 & 1.5 & 4.9 & 4.8 & 2.8 \\
$\mathrm{Mn}$ & $\mathrm{mg} / \mathrm{kg}$ & 508.5 & 542.7 & 522.9 & 629.7 & 539.6 & 517.2 & 648.4 \\
$\mathrm{Mo}$ & $\mathrm{mg} / \mathrm{kg}$ & 3.0 & 3.4 & 2.5 & 2.6 & 2.9 & 3.2 & 3.1 \\
$\mathrm{~Pb}$ & $\mathrm{mg} / \mathrm{kg}$ & 17.4 & 21.8 & 13.5 & 13.3 & 12.7 & 16.4 & 22.6 \\
$\mathrm{Zn}$ & $\mathrm{mg} / \mathrm{kg}$ & 44.1 & 50.1 & 92.7 & 69.3 & 60.6 & 100.2 & 80.3 \\
\hline
\end{tabular}

${ }^{\text {a }}$ ClLm: clay loam; Cl: Clay; Lm: loam

Table 2. Summary statistics of physico-chemical parameters and eleven potentially toxic heavy metals in sediment samples collected in the Soubeira reservoir

\begin{tabular}{llllllllll}
\hline Parameter & Unit & $\mathbf{N}$ & Min. & Max. & Average & Median & SD $^{\mathbf{a}}$ & $\mathbf{C V}(\mathbf{\%})^{\mathbf{b}}$ & Skewness \\
\hline $\mathrm{pH}_{\mathrm{H} 2 \mathrm{O}}$ & & 7 & 5.4 & 8.8 & 6.1 & 5.5 & 1.2 & 20.1 & $\mathbf{2 . 7}$ \\
$\mathrm{TOC}$ & $\%$ & 7 & 0.3 & 1.3 & 0.8 & 0.8 & 0.38 & 47.8 & -0.1 \\
$\mathrm{CEC}$ & $\mathrm{cmol}_{\mathrm{c}} / \mathrm{kg}$ & 7 & 5.3 & 13.2 & 9.2 & 10.7 & 2.9 & 29.0 & -1.0 \\
$\mathrm{Clay}$ & $\%$ & 7 & 33.3 & 54.9 & 43.1 & 47.1 & 8.09 & 18.7 & -0.1 \\
$\mathrm{Silt}$ & $\%$ & 7 & 27.5 & 43.1 & 35.9 & 37.3 & 5.40 & 15.0 & -0.3 \\
$\mathrm{Sand}$ & $\%$ & 7 & 9.8 & 39.2 & 21.0 & 13.7 & 11.47 & 54.6 & 0.7 \\
$\mathrm{Fe}$ & $\mathrm{mg} / \mathrm{kg}$ & 7 & 14620 & 29024 & 22131 & 22138 & 4259 & 19.0 & -0.3 \\
$\mathrm{As}$ & $\mathrm{mg} / \mathrm{kg}$ & 7 & 10.1 & 17 & 12.1 & 11.3 & 2.15 & 17.9 & 1.9 \\
$\mathrm{Cd}$ & $\mathrm{mg} / \mathrm{kg}$ & 7 & 0.9 & 1.0 & 0.9 & 0.9 & 0.07 & 7.4 & 1.2 \\
$\mathrm{Co}$ & $\mathrm{mg} / \mathrm{kg}$ & 7 & 8.6 & 18 & 12.7 & 12.6 & 2.69 & 21.2 & 0.7 \\
$\mathrm{Cr}$ & $\mathrm{mg} / \mathrm{kg}$ & 7 & 54.2 & 77.0 & 68.2 & 70.6 & 7.4 & 10.8 & 1.6 \\
$\mathrm{Cu}$ & $\mathrm{mg} / \mathrm{kg}$ & 7 & 26.8 & 53.0 & 37.6 & 37.5 & 9.3 & 24.8 & 0.4 \\
$\mathrm{Hg}$ & $\mathrm{mg} / \mathrm{kg}$ & 7 & 1.4 & 5.0 & 2.9 & 2.6 & 1.44 & 49.2 & 0.7 \\
$\mathrm{Mn}$ & $\mathrm{mg} / \mathrm{kg}$ & 7 & 508 & 648 & 558 & 539 & 57 & 10.1 & 1.1 \\
$\mathrm{Mo}$ & $\mathrm{mg} / \mathrm{kg}$ & 7 & 2.5 & 3.0 & 2.9 & 3.0 & 0.32 & 10.8 & -0.4 \\
$\mathrm{~Pb}$ & $\mathrm{mg} / \mathrm{kg}$ & 7 & 12.7 & 23 & 16.8 & 16.4 & 4.05 & 24.1 & 0.6 \\
$\mathrm{Zn}$ & $\mathrm{mg} / \mathrm{kg}$ & 7 & 44.1 & 100 & 71.1 & 69.3 & 21.13 & 29.7 & 0.1 \\
\hline
\end{tabular}

${ }^{a} \mathrm{SD}$ : standard deviation; ${ }^{\mathrm{b}} \mathrm{CV}$ : coefficient of variance $(\mathrm{CV}=(\mathrm{SD} /$ average $) * 100)$ 


\subsection{Spatial Distribution Patterns of Heavy Metals}

The concentrations of heavy metals in the Soubeira reservoir decreased in the following sequence: $\mathrm{Fe}>\mathrm{Mn}>\mathrm{Cr}>$ $\mathrm{Zn}>\mathrm{Cu}>\mathrm{Pb}>\mathrm{As} \sim \mathrm{Co}>\mathrm{Hg} \sim \mathrm{Mo}>\mathrm{Cd}$. The relative high Fe concentrations observed in the present samples reflect the presence of ferruginous nodules in the sediments. Thus, the high concentrations of $\mathrm{Mn}$ and Fe could be due to erosion of the parent rock and its subsequent transport into the reservoir. With skewness values less than 2 , all heavy metals were normally distributed. The total concentrations of the heavy metals in the sediment samples followed the order of site- $7>$ site- $5>$ site-3> site- $1>$ site- $2>$ site- $1>$ site- 6 (Fig. 2). The average concentrations of $\mathrm{As}, \mathrm{Hg}$ and $\mathrm{Cr}$ in the sediments exceeded the average world's soil concentrations (Kabata-Pendias, 2011).

Spatial distribution maps of heavy metals in the sediments were produced using PAST3 software (Hammer et al., 2001). After normality test and semivariogram modeling, an ordinary kriging interpolation method was used to construct spatial distribution maps of individual heavy metals (Fig. 3). Patches of maximum concentrations of $\mathrm{Co}, \mathrm{Mn}, \mathrm{Cu}, \mathrm{Hg}, \mathrm{Fe}, \mathrm{Pb}$ and $\mathrm{Zn}$ were found around the reservoir inlet (Sites 6 and 7). On the contrary, As spread from site 5 to sites 4 and 7 , whereas $\mathrm{Cd}$ was concentrated around site 6 . Because of their high affinity for fine-grained particles, the maximum concentrations of $\mathrm{Cr}$ and $\mathrm{Pb}$ were observed in sites $(2,5$ and 3$)$ with the highest clay contents. The spatial distribution of Mo showed a homogenous pattern across the reservoir with the highest concentrations around site 2 .

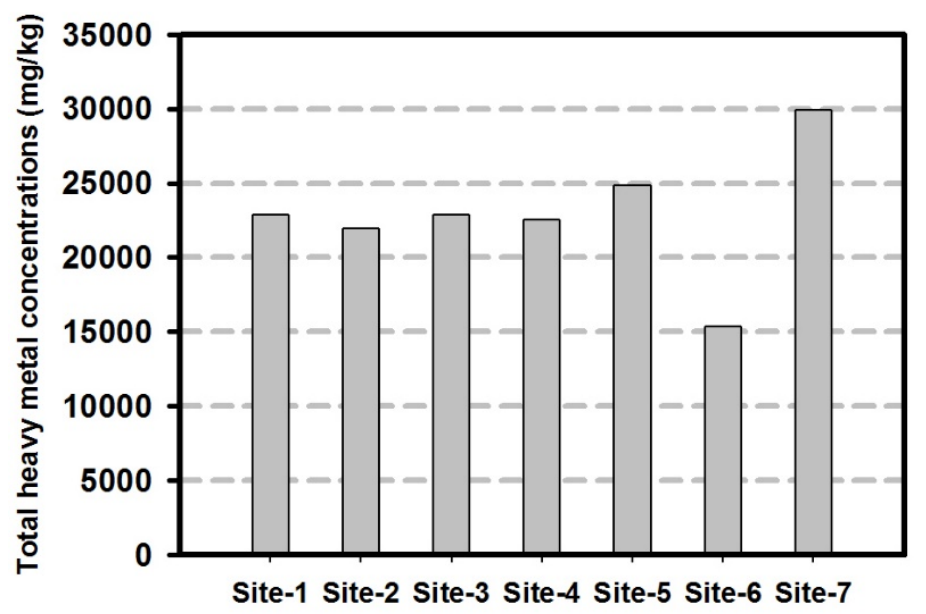

Figure 2. Total concentrations of 11 heavy metals (Fe, $\mathrm{As}, \mathrm{Cd}, \mathrm{Co}, \mathrm{Cr}, \mathrm{Cu}, \mathrm{Hg}, \mathrm{Mn}, \mathrm{Mo}, \mathrm{Pb}$ and $\mathrm{Zn}$ ) in the Soubeira reservoir sediments 

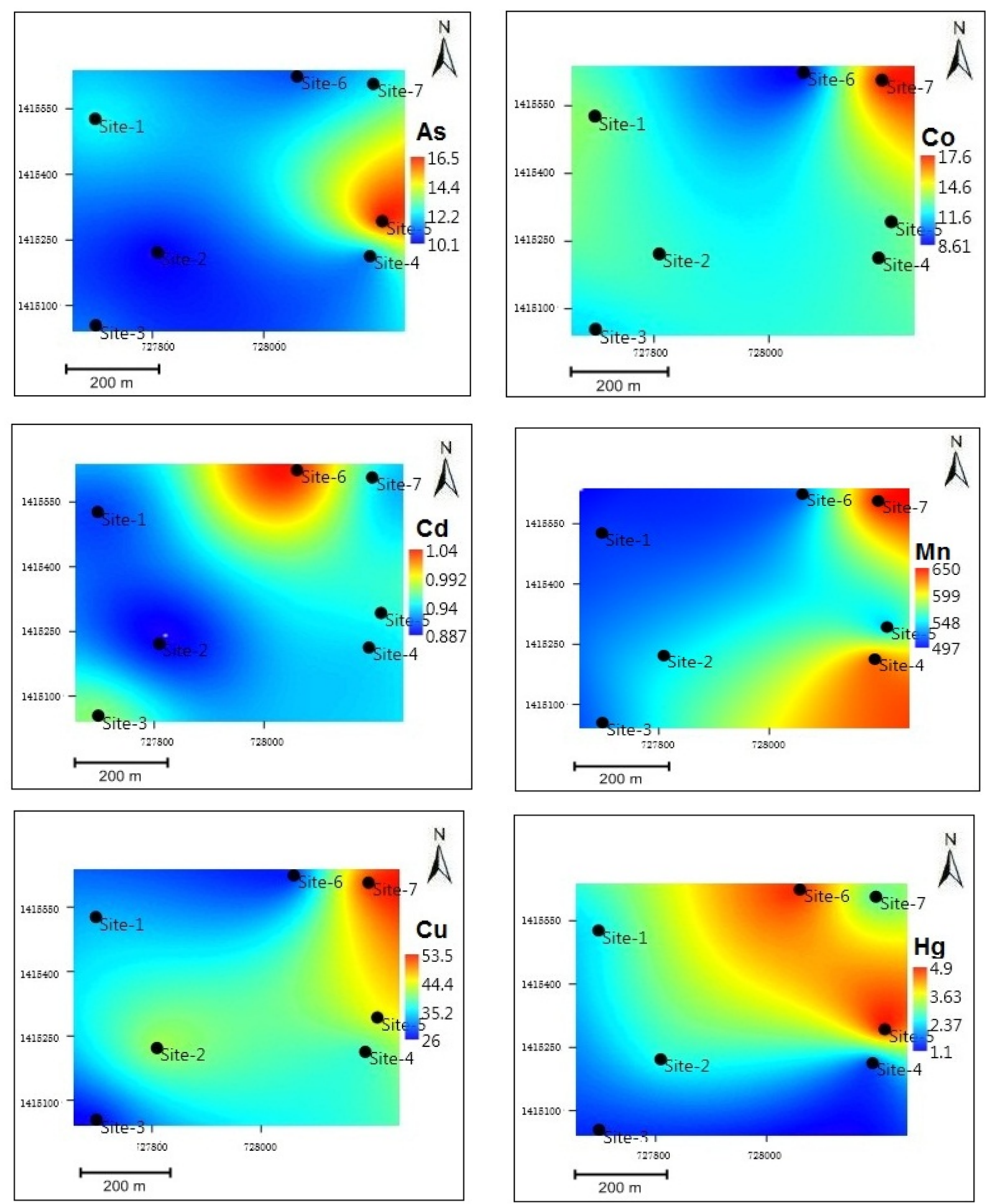

Figure 3. Spatial distribution patterns of $\mathrm{As}, \mathrm{Co}, \mathrm{Cd}, \mathrm{Mn}, \mathrm{Cr}, \mathrm{Cu}, \mathrm{Hg}, \mathrm{Pb}$, Mo and $\mathrm{Zn}$ in the sediment samples from the Soubeira reservoir 

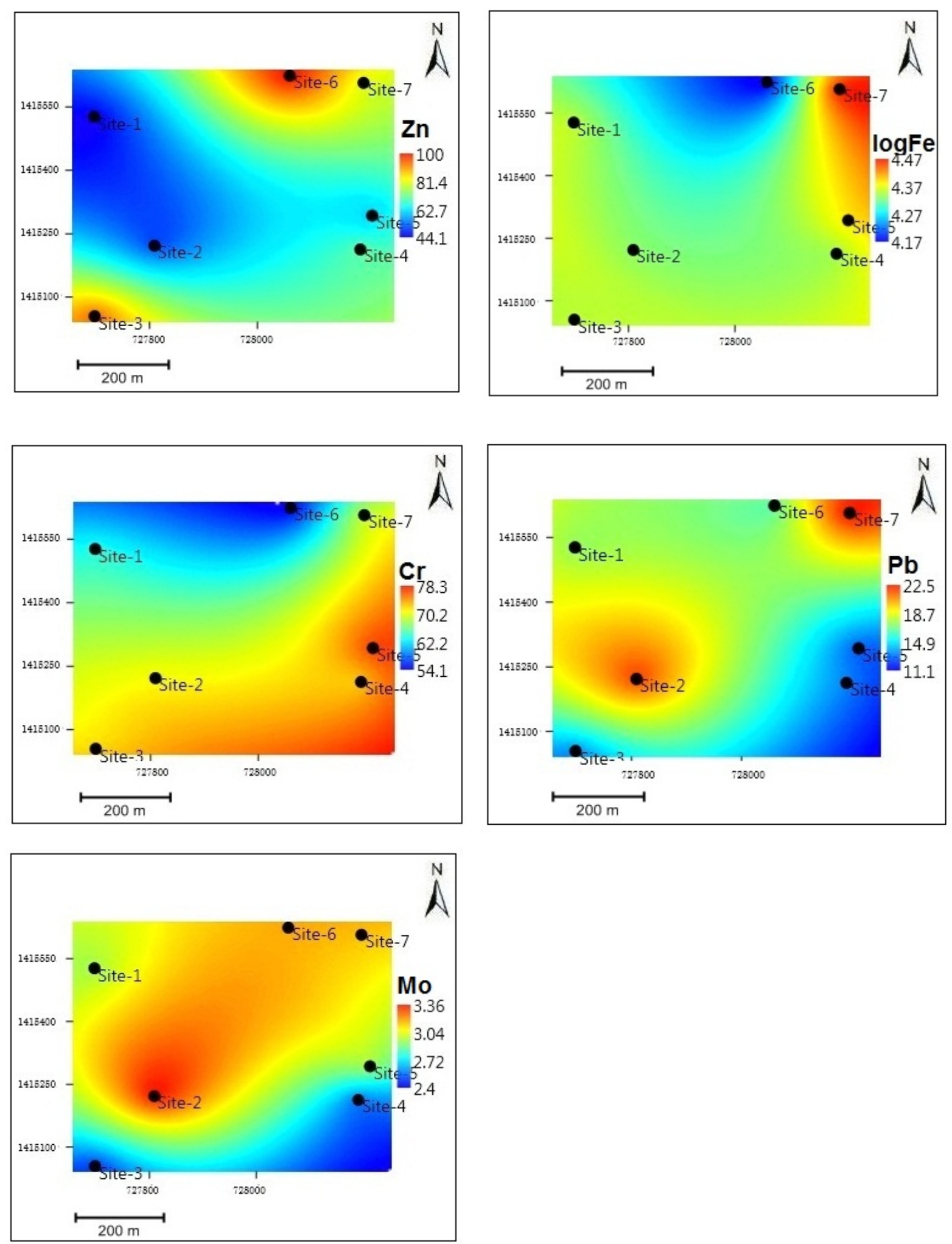

Figure 3. continued 


\subsection{Potential Sources of Heavy Metals}

The concentrations and distribution of the investigated heavy metals can have both geogenic and anthropogenic sources. In order to assess the relationships between the metals and physico-chemical parameters (i.e., variables) and to identify their potential sources and loading pathways into the reservoir, Pearson's correlation matrix was used. Thus, a significant correlation between two variables indicates that they have common sources, mutual dependence or identical behavior during transport and resuspension in the aquatic environment (Suresh et al., 2011).

As expected, strong positive correlations $(\mathrm{p}<0.05)$ were observed between clay, TOC and CEC, suggesting that clay and TOC contributed to CEC (Table 3). Negative correlations between $\mathrm{pH}$ and $\mathrm{Cr}(\mathrm{r}=-0.61)$, Mo $(\mathrm{r}=-0.59)$ and, to a lesser extent, $\mathrm{Mn}(-0.44)$ are consistent with the high solubility of these metals under low $\mathrm{pH}$ conditions. Cadmium, $\mathrm{Cr}, \mathrm{Cu}, \mathrm{Co}$ and $\mathrm{Mn}$ exhibited strong correlations with both clay and $\mathrm{CEC}$, implying a strong affinity of these divalent cations for negatively charged aluminosilicate minerals (Aguilar et al., 2012). As a result, clay constitutes an important factor for these metals' immobility in the Soubeira reservoir. Significant relationships were also observed between TOC and Mn $(r=0.75)$ and TOC and $\mathrm{Cr}(\mathrm{r}=0.77)$, suggesting that TOC was a scavenger of $\mathrm{Mn}$ and $\mathrm{Cr}$ in the sediments. Because of noticeable significant positive relationships between $\mathrm{Cr}$ and $\mathrm{Cd}(\mathrm{r}=0.83), \mathrm{Cu}$ and $\mathrm{Cd}(\mathrm{r}=0.95)$, it can be therefore assumed that these metals were mainly originated from common anthropogenic sources and carried by fine-grained particles into the reservoir. High $\mathrm{Cu}$ and $\mathrm{Cd}$ concentrations in sediments have been attributed to wastewater discharges and agricultural runoff (González et al., 2006; Aguilar et al., 2012; Zeng and Wu, 2013). In the Soubeira reservoir drainage basin, agriculture is the main economic activity, which generates large quantities of Wastes through the use of inorganic fertilizers. These wastes generally contain large amounts of $\mathrm{Cd}$ and other heavy metals.

Table 3. Pearson's correlation matrix of the Soubeira reservoir sediment samples

\begin{tabular}{|c|c|c|c|c|c|c|c|c|c|c|c|c|c|c|c|}
\hline Variable & pH & CEC & TOC & Clay & $\mathrm{Fe}$ & As & Cd & Co & $\mathrm{Cr}$ & $\mathrm{Cu}$ & $\mathrm{Hg}$ & Mn & Mo & $\mathbf{P b}$ & $\mathbf{Z n}$ \\
\hline pH & 1.00 & & & & & & & & & & & & & & \\
\hline CEC & -0.50 & 1.00 & & & & & & & & & & & & & \\
\hline TOC & -0.72 & 0.75 & 1.00 & & & & & & & & & & & & \\
\hline Clay & -0.64 & 0.96 & 0.83 & 1.00 & & & & & & & & & & & \\
\hline $\mathrm{Fe}$ & -0.21 & 0.28 & 0.42 & 0.26 & 1.00 & & & & & & & & & & \\
\hline As & 0.29 & -0.75 & -0.34 & -0.64 & -0.05 & 1.00 & & & & & & & & & \\
\hline Cd & -0.25 & 0.79 & 0.48 & 0.82 & 0.21 & -0.65 & 1.00 & & & & & & & & \\
\hline Co & 0.10 & 0.69 & 0.50 & 0.52 & 0.43 & -0.53 & 0.44 & 1.00 & & & & & & & \\
\hline $\mathrm{Cr}$ & -0.61 & 0.93 & 0.77 & 0.97 & 0.37 & -0.56 & 0.83 & 0.48 & 1.00 & & & & & & \\
\hline $\mathrm{Cu}$ & -0.08 & 0.79 & 0.45 & 0.76 & 0.37 & -0.61 & 0.95 & 0.64 & 0.79 & 1.00 & & & & & \\
\hline $\mathrm{Hg}$ & -0.44 & -0.12 & 0.14 & -0.03 & 0.54 & 0.45 & -0.28 & -0.31 & 0.13 & -0.27 & 1.00 & & & & \\
\hline Mn & -0.41 & 0.66 & 0.75 & 0.78 & -0.05 & -0.28 & 0.69 & 0.34 & 0.68 & 0.60 & -0.29 & 1.00 & & & \\
\hline Mo & -0.59 & 0.25 & 0.05 & 0.30 & -0.10 & -0.16 & 0.09 & -0.37 & 0.40 & -0.07 & 0.53 & -0.09 & 1.00 & & \\
\hline $\mathbf{P b}$ & -0.37 & 0.43 & 0.005 & 0.47 & -0.42 & -0.42 & 0.51 & -0.23 & 0.51 & 0.31 & -0.05 & 0.27 & 0.77 & 1.00 & \\
\hline $\mathbf{Z n}$ & 0.41 & -0.51 & -0.27 & -0.40 & -0.26 & 0.86 & -0.31 & -0.36 & -0.35 & -0.29 & 0.13 & 0.08 & -0.24 & -0.20 & 1.00 \\
\hline
\end{tabular}

Correlation coefficients in bolds are significant at $\mathrm{p}$-value $<0.05$

The high correlation between As and $\mathrm{Zn}(\mathrm{r}=0.86)$ suggests that the abundance of these two metals in the Soubeira reservoir was controlled by similar geochemical processes. Significant negative correlations between $\mathrm{CEC}$ and $\mathrm{As}(\mathrm{r}=-0.75)$ and $\mathrm{Zn}(\mathrm{r}=-0.51)$ indicates that a decrease in basic cations in sediments (i.e., $\mathrm{pH})$ will enhance $\mathrm{As}$ and $\mathrm{Zn}$ adsorption. However, the negative relationships between clay and As and $\mathrm{Zn}$, implies that the physico-chemical conditions of the reservoir do not favor As and $\mathrm{Zn}$ retention and accumulation by the sediments. Regardless to the total concentrations, As and $\mathrm{Zn}$ are likely to be highly mobile and bioavailable within the reservoir. The range of Mo abundance in the present sediment samples is similar to those found in the world's soils, and thus it can be concluded that Mo is primarily derived from a geogenic source. The significant 
positive correlation between $\mathrm{Mo}$ and $\mathrm{Pb}(\mathrm{r}=0.77)$, implies that $\mathrm{Pb}$ is also mainly of a natural source. Iron exhibited weaker relationships with other heavy metals suggesting that $\mathrm{Fe}$ abundance in the sediments were not controlled by a single factor. That is, Fe may be controlled by a combination of geochemical phases as well as by the regional ferruginous soil signatures. The low CV (19\%) of Fe indicates the homogenous distribution of this metal, and thereby reflects its intrinsic nature within the reservoir. In contrast, $\mathrm{Hg}$ had the highest CV (49.2\%) among the investigated heavy metals with only a moderate correlation with $\mathrm{Fe}(\mathrm{r}=0.54)$. Thus, it can be suggested that a relative high $\mathrm{Hg}$ concentrations were anthropogenically driven. Artisanal gold mining in the area $(\sim 1.5 \mathrm{~km}$ from the reservoir) could be the primarily source of $\mathrm{Hg}$ loadings into the reservoir. In addition to destruction of soil structure and increase in erosion rate, artisanal mining uses metallic mercury $\left(\mathrm{Hg}^{0}\right)$ to extract gold from crude ore. This activity releases large amounts of mine wastes enriched with toxic heavy metals (e.g., $\mathrm{Hg}$ and As), which are poorly managed and end up in the reservoir through rivers and streams. The moderate correlation between $\mathrm{Hg}$ and $\mathrm{As}(\mathrm{r}=0.45)$ can be explained by the fact that $\mathrm{Hg}^{0}$ is manually added to sediments through $\mathrm{Hg}$-amalgamation, whereas As is present in geological materials and dispersed into the reservoir through mining activities. As a result, the two mining-derived metals may not necessary behave in the same way in the sediments (Donkor et al., 2005).

\subsection{Potential Ecological Risk and Adverse Effect Assessment}

In the absence of toxicity study data, PERI that takes into account both total and toxic-response factors can be used to identify which heavy metals and aquatic systems need to be given a special attention (Håkanson, 1980). Contrary to single geochemical indices (e.g., geoaccumultion index and enrichment factor), PERI simultaneously evaluates the combined effects of several pollutants. Therefore, PERI was used in this study to assess the potential ecological risk of seven potentially harmful heavy metals ( $\mathrm{As}, \mathrm{Cd}, \mathrm{Cr}, \mathrm{Cu}, \mathrm{Hg}, \mathrm{Pb}$ and $\mathrm{Zn}$ ) as follows:

$$
\begin{gathered}
C_{f}^{i}=\frac{C_{i}}{C_{n}^{i}} \\
E_{r}^{i}=T_{r}^{i} x C_{f}^{i} \\
\mathrm{RI}=\Sigma E_{r}^{i}
\end{gathered}
$$

Where $C_{f}^{i}$ is the pollution factor of a metal $i ; C_{i}$ is the measured concentration of the metal $i$ in the sediment samples; $C_{n}^{i}$ represents the pre-industrial reference concentration of the metal in sediments. In the present study, the pre-industrial concentrations for $\mathrm{As}, \mathrm{Cd}, \mathrm{Cr}, \mathrm{Cu}, \mathrm{Hg}, \mathrm{Pb}$ and $\mathrm{Zn}$ are 15, 0.5, 60, 30, 0.2, 25 and $80 \mathrm{mg} / \mathrm{kg}$, respectively (Hilton et al., 1985). $\mathrm{E}_{\mathrm{r}}^{\mathrm{i}}$ is the potential risk of individual metals and $\mathrm{T}_{\mathrm{r}}^{\mathrm{i}}$ is the biological toxic-response factor for a metal that accounts for the toxic and sensitivity requirements taken as $\mathrm{As}=10, \mathrm{Cd}=$ $30, \mathrm{Cr}=2, \mathrm{Cu}=30, \mathrm{Hg}=40, \mathrm{~Pb}=5$ and $\mathrm{Zn}=1$ (Håkanson, 1980; Hilton et al., 1985; Wang et al., 2011) and $\mathrm{RI}$ is the sum of potential risk of the individual metals. Håkanson defined five categories for RI and four categories for potential ecological risk (Table 4).

Table 4. Ecological risk indices and corresponding risk factor for individual metals $\left(\mathrm{E}_{\mathrm{r}}^{\mathrm{i}}{ }^{\mathrm{i}}\right.$ and potential ecological risk index for the environment (RI) as suggested by Håkanson (1980)

\begin{tabular}{llll}
\hline $\mathbf{E}_{\mathbf{r}}{ }^{\mathrm{i}}$ values & $\begin{array}{l}\text { Grade of ecological risk } \\
\text { for single metal }\end{array}$ & RI values & $\begin{array}{l}\text { Grade of potential ecological } \\
\text { risk for the environment }\end{array}$ \\
\hline $\mathrm{E}_{\mathrm{r}}^{\mathrm{i}}<40$ & low & $\mathrm{RI}<95$ & low \\
$40 \leq \mathrm{E}_{\mathrm{r}}{ }^{\mathrm{i}}<80$ & moderate & $95 \leq \mathrm{RI}<190$ & moderate \\
$80 \leq \mathrm{E}_{\mathrm{r}}{ }_{\mathrm{i}}<160$ & Considerable & $190 \leq \mathrm{RI}<380$ & Considerable \\
$160 \leq \mathrm{E}_{\mathrm{r}}^{\mathrm{i}} \leq 360$ & High & & \\
$\mathrm{E}_{\mathrm{r}}^{\mathrm{i}} \geq 320$ & very high & $\mathrm{RI} \geq 380$ & very high \\
\hline
\end{tabular}

Mercury had the highest $\mathrm{E}_{\mathrm{r}}^{\mathrm{i}}$ values (average $\left.=585 \pm 288\right)$ followed by $\mathrm{Cd}(56 \pm 4.2)$, indicating high and moderate ecological risk of $\mathrm{Hg}$ and $\mathrm{Cd}$, respectively (Table 5). Other heavy metals ( $\mathrm{As}, \mathrm{Cu}, \mathrm{Cr}, \mathrm{Pb}$ and $\mathrm{Zn}$ ) had $\mathrm{E}_{\mathrm{r}}^{\mathrm{i}}$ less than 10, implying their low potential ecological risk. Based on the calculated RI $(663 \pm 291)$, the 
Soubeira reservoir exhibited very high potential ecological risk. The inlet area (sites 5,6 and 7), with high $\mathrm{E}_{\mathrm{r}}^{\mathrm{i}}$ and RI, are considered as hotspots of $\mathrm{Hg}$ and $\mathrm{Cd}$ pollution. In overall, PERI indicates possible toxicity of benthic organisms of the Soubeira reservoir. According to $\mathrm{E}_{\mathrm{r}}^{\mathrm{i}}$ and PERI, sites 5, 6 and 7, with the highest indices, need particular attention within the reservoir.

Table 5. Potential ecological risk indices of individual heavy metals $\left(\mathrm{E}_{\mathrm{r}}^{\mathrm{i}}\right)$ and potential ecological risk indices of the sites (RI)

\begin{tabular}{lllllllll}
\hline Site & $\mathbf{E}_{\mathbf{r}}^{\mathbf{i}}$ & & & & & & & RI \\
\cline { 2 - 9 } & $\mathbf{A s}$ & $\mathbf{C d}$ & $\mathbf{C r}$ & $\mathbf{C u}$ & $\mathbf{H g}$ & $\mathbf{P b}$ & $\mathbf{Z n}$ & \\
\hline Site-1 & 8.3 & 53.4 & 2.1 & 5.5 & 484 & 3.5 & 0.6 & 557 \\
Site-2 & 6.7 & 52.2 & 2.4 & 6.9 & 514 & 4.4 & 0.6 & 587 \\
Site-3 & 7.4 & 59.4 & 2.4 & 4.5 & 278 & 2.7 & 1.2 & 355 \\
Site-4 & 7.6 & 55.8 & 2.4 & 6.2 & 302 & 2.7 & 0.9 & 378 \\
Site-5 & 11.1 & 57.0 & 2.6 & 7.4 & 988 & 2.5 & 0.8 & 1069 \\
Site-6 & 7.2 & 64.8 & 1.8 & 4.6 & 966 & 3.3 & 1.3 & 1049 \\
Site-7 & 8.1 & 55.2 & 2.3 & 8.8 & 564 & 4.5 & 1.0 & 644 \\
\hline Min. & 6.7 & 52.2 & 1.8 & 4.5 & 278 & 2.5 & 0.6 & 355 \\
Max. & 11.1 & 64.8 & 2.6 & 8.8 & 988 & 4.5 & 1.3 & 1069 \\
Average & 8.0 & 56.8 & 2.3 & 6.3 & 585 & 3.4 & 0.9 & 663 \\
SD & 1.4 & 4.2 & 0.2 & 1.6 & 288 & 0.8 & 0.3 & 291 \\
CV (\%) & 17.9 & 7.4 & 10.8 & 24.8 & 49 & 24.1 & 29.7 & 44 \\
PER grade & low & moderate & low & low & very high & low & low & very high \\
\hline
\end{tabular}

The extents of the adverse effects (AEI) of the seven heavy metals on the benthic biota were assessed by comparing total concentrations of individual heavy metals to their threshold effect levels (Munñoz-Barboza et al., 2012; Baraud et al., 2017) as follows:

$$
\mathrm{AEI}=\frac{\left[M_{i}\right]}{T E L}
$$

Where $\left[\mathrm{M}_{\mathrm{i}}\right]$ is the concentration of the heavy metal $\mathrm{i}$; TEL is the Threshold Effect Level of the metal $\mathrm{i}$, a minimum concentration below which adverse biological effects are expected to occur rarely. The TEL values used in this study are: 7.2, 0.68, 52.8, 18.7, 0.174, 30.2 and $124 \mathrm{mg} / \mathrm{kg}$ for $\mathrm{As}, \mathrm{Cd}, \mathrm{Cr}, \mathrm{Cu}, \mathrm{Hg}, \mathrm{Pb}$ and $\mathrm{Zn}$, respectively (CCME, 2001). According to Eq. 4, if the AEI is less than 1, the concentration of a metal is not high enough to cause adverse effects to the benthic organisms. In contrast, an AEI value greater than 1, suggests that the metal could cause adverse biological effects. Except $\mathrm{Pb}$ and $\mathrm{Zn}$, the heavy metal concentrations in the Soubeira sediment samples exceeded the TEL in the following decreasing order: $\mathrm{Hg}>\mathrm{Cu}>\mathrm{As}>\mathrm{Cd}>\mathrm{Cr}>\mathrm{Pb} \sim$ $\mathrm{Zn}$ ). With the average AEI value of $28.4 \pm 16.8, \mathrm{Hg}$ is the most likely to induce negative biological effects followed by $\mathrm{Cu}, \mathrm{Cd}$ and $\mathrm{Cr}$ (Table 6). In accordance with RI, AEI values showed that the Soubeira reservoir was highly polluted, and that it needs particular remediation efforts. Furthermore, the two assessment techniques identified $\mathrm{Hg}$ as the biggest pollutant in the reservoir. Likewise, the low RI and AEI values of $\mathrm{Pb}$ and $\mathrm{Zn}$ imply that the concentrations of these two metals do not pose serious threat to benthic ecosystem. However, the difference between $\mathrm{E}_{\mathrm{r}}^{\mathrm{i}}$ and AEI values is reflected on the results of $\mathrm{As}, \mathrm{Cd}$ and, to a lesser degree, Cr. Thus, potential ecological risk indices showed that $\mathrm{Cd}$ had moderate effects and low effects for As and Cr, whereas AEI values suggested adverse biological effects for all metals except $\mathrm{Pb}$ and $\mathrm{Zn}$. Therefore, AEI values are more stringent and conservative for monitoring heavy metal pollution of the reservoir than these of potential ecological risk index for individual metals (i.e., $\mathrm{E}_{\mathrm{r}}^{\mathrm{i}}$ ). 
Table 6. Adverse Effect indices of seven potentially harmful heavy metals in the Soubeira reservoir sediment samples

\begin{tabular}{lccccccc}
\hline Site & As & $\mathbf{C d}$ & $\mathbf{C r}$ & $\mathbf{C u}$ & $\mathbf{H g}$ & $\mathbf{P b}$ & $\mathbf{Z n}$ \\
\hline Site-1 & $\mathbf{1 . 7}$ & $\mathbf{1 . 3}$ & $\mathbf{1 . 2}$ & $\mathbf{1 . 8}$ & $\mathbf{1 3 . 9}$ & 0.6 & 0.4 \\
Site-2 & $\mathbf{1 . 4}$ & $\mathbf{1 . 3}$ & $\mathbf{1 . 3}$ & $\mathbf{2 . 2}$ & $\mathbf{1 4 . 8}$ & 0.7 & 0.4 \\
Site-3 & $\mathbf{1 . 5}$ & $\mathbf{1 . 5}$ & $\mathbf{1 . 4}$ & $\mathbf{1 . 4}$ & $\mathbf{8 . 0}$ & 0.4 & 0.7 \\
Site-4 & $\mathbf{1 . 6}$ & $\mathbf{1 . 4}$ & $\mathbf{1 . 4}$ & $\mathbf{2 . 0}$ & $\mathbf{8 . 7}$ & 0.4 & 0.6 \\
Site-5 & $\mathbf{2 . 3}$ & $\mathbf{1 . 4}$ & $\mathbf{1 . 5}$ & $\mathbf{2 . 4}$ & $\mathbf{2 8 . 4}$ & 0.4 & 0.5 \\
Site-6 & $\mathbf{1 . 5}$ & $\mathbf{1 . 6}$ & $\underline{1.0}$ & $\mathbf{1 . 5}$ & $\mathbf{2 7 . 8}$ & 0.5 & 0.8 \\
Site-7 & $\mathbf{1 . 7}$ & $\mathbf{1 . 4}$ & $\mathbf{1 . 3}$ & $\mathbf{2 . 8}$ & $\mathbf{1 6 . 2}$ & 0.7 & 0.6 \\
\hline Min. & 1.4 & 1.3 & 1.0 & 1.4 & 8.0 & 0.4 & 0.4 \\
Max. & 2.3 & 1.6 & 1.5 & 2.8 & 28.4 & 0.7 & 0.8 \\
Average & 1.7 & 1.4 & 1.3 & 2.0 & 16.8 & 0.6 & 0.6 \\
SD & 0.3 & 0.1 & 0.1 & 0.5 & 8.3 & 0.1 & 0.2 \\
CV (\%) & 17.9 & 7.4 & 10.8 & 24.8 & 49.2 & 24.1 & 29.7 \\
\hline
\end{tabular}

\section{Conclusions}

The results of this study indicated that the Soubeira reservoir was not sufficiently protected against the pollution of heavy metals, and the pollution was more pronounced around to the reservoir inlet.

Correlation analyses indicated that $\mathrm{Cd}, \mathrm{Cu}$ and $\mathrm{Cr}$ were predominately derived from agricultural and untreated wastewater sources, and their mobility within the reservoir is likely to be controlled by clay minerals. Artisanal gold mining appeared to be the main source of As and $\mathrm{Hg}$ in the reservoir, whereas $\mathrm{Fe}, \mathrm{Mn}$ and $\mathrm{Zn}$ abundances could be attributed to geogenic sources. Both RI and AEI showed that heavy metal pollution occurred in the Soubeira reservoir sediments. Mercury appeared to be the only metal posing serious ecological risk to sediment-dwelling organisms. According to AEI values, $\mathrm{Hg}, \mathrm{As}, \mathrm{Cd}, \mathrm{Cu}$ and $\mathrm{Cr}$ are predicted to produce adverse biological effects. The study demonstrated that the Soubeira reservoir is exposed to high loadings of potentially harmful heavy metals, and hence urgently need a sound environmental monitoring program.

\section{Acknowledgements}

Our special thanks to Samuel Nacolondoussé and Ibrahim Sory for laboratory analyses, Saga Sawadogo for compiling location and sampling maps. This work benefited from the FasoReg financial support. Logistic assistance from Francis Guyon is greatly appreciated. We would also like to thank the editor and an anonymous reviewer for their helpful suggestions and comments.

\section{References}

Aguilar, C. A., Montalvo, C., Rodríguez, L., Cerón, J. G., \& Cerón, R. M. (2012). American oyster (Crassostrea virginica) and sediments as a coastal zone pollution monitor by heavy metals. International Journal of Environmental Sciences Technology, 9, 579-586. https://doi.org/10.1007/s13762-012-0078-y

Baraud, F., Leleyter, L., Lemoine, M., \& Hamdoun, H. (2017). Cr in dredged marine sediments: Anthropogenic enrichment, bioavailability and potential adverse effects. Marine Pollution Bulletin, 15, 303-308. https://doi.org/10.1016/j.marpolbul.2017.05.039

Boelee, E., Cecchi, P., \& Koné, A. (2009). Health impacts of small reservoirs in Burkina Faso. Working Paper No. 136. Colombo, Sri Lanka: IWMI.

Boulet, R. (1968). Carte pédologique de reconnaissance de la Haute Volta (Centre-nord), 11500000. ORSTOM, Paris, France.

Bruder, H. V., Lagarde, F., Leroy, M. J. F., Coughanowr, C., \& Enguehard, F. (2002). Application of a sequential extraction procedure to study the release of elements from municipal solid waste incineration bottom ash. Analytica Chimica Acta, 451, 285-295. https:// doi.org/10.1016/S0003-2670(01)01403-9

BUNASOL. (1990). Plan régional du secteur agro-pastoral de l'ex. ORD du Centre-nord. Tomes 1, 2, 3. Ministère de l'agriculture et de l'élevage. 
Calmano, W. (1988). Stabilization of dredged mud. Environmental management of solid waste. Springer, Berlin, pp 80-98

Calmano, W., Ahlf, W., \& Förstner, U. (1990). Exchange of heavy metals between sediment components and water. In Broekaert, J. A. C., Güçer, Ş., \& Adams, F. (Eds.), Metal Speciation in the Environment: NATO ASI Series (Vol. G 23, pp. 503-522). Springer-Verlag, Berlin.

Calmano, W., Hong, J., \& Förstner, U. (1993). Binding and mobilization of heavy metals in contaminated sediments affected by $\mathrm{pH}$ and redox potential. Water Science \& Technology, 28, 223-223. https://doi.org/10.15480/882.450

CCME (Canadian Council of Ministers of the Environment). (2001). Protocol for the derivation of Canadian sediment quality guidelines for the protection of aquatic life. CCME EPC-98E. Prepared by Environment Canada, Guidelines Division, Technical Secretariat of the CCME Task Group on Water Quality Guidelines, Ottawa.

Cecchi, P. (2007). L'eau en partage. Les petits barrages de Côte d'Ivoire. Paris: IRD Editions.

Cecchi, P., Meunier-Nikiema, A., Moiroux, N., \& Sanou, B. (2009). Towards an atlas of lakes and reservoirs in Burkina Faso. In Andreini, M., Schuetz, T., \& Harrington, L. B. (Eds.), Small reservoirs toolkit (pp.23). Sri Lanka: IWMI.

Cecchi, P., Zerbo, P., Berger, C., \& Zongo, F. (2004). Existe-t-il un risque de toxicité associé aux proliférations de cyanobactéries dans le réservoir de Loumbila? Journées Scientifiques du Groupe des Ecoles EIER ETSHER, 2004/12/06, Ouagadougou, 5p.

Choi, S. D., \& Wania, F. (2011). On the reversibility of environmental contamination with persistent organic pollutants. Environmental Science \& Technology, 45, 8834-8841. https://doi.org/10.1021/es2017544

Cook, J. A., Andrew, S. M., \& Johnson, M. S. (1990). Lead, zinc, cadmium and fluoride in small Mammals from contaminated grass-land established on fluorspar tailings. Water Air Soil \& Pollution, 51, 43-54. https://doi.org/10.1007/BF00211502

Deniseger, J., Erickson, J., Austin, A., Roch, M., \& Clark, M. J. R. (1990). The effects of decreasing heavy metal concentrations on the biota of Buttle Lake. Water Research, 24, 403-416. https://doi.org/10.1016/0043-1354(90)90222-R

Donkor, A. K., Bonzongo, J. C. J., Nartey, V. K., \& Adotey, D. K. (2005). Heavy metals in sediments of the gold mining impacted Pra River basin, Ghana, West Africa. Soil \& Sediment. Contamination, 14(6), 479-503. https://doi.org/10.1080/15320380500263675

Ersado, L. (2005). Small-scale irrigation dams, agricultural production and health: Theory and evidence from Ethiopia. World Bank Policy Research Paper No. 3494. Washington, DC: The World Bank.

Fontes, J., \& Guinko, S. (1995). Carte de la végétation et de l'occupation du sol au Burkina Faso,1/1000000, notice explicative. Ouagadougou, Burkina Faso: Ministère de la coopération française. Projet campus. Institut du développement Rural. Faculté des sciences et techniques, Université de Ouagadougou. 67p.

Förstner, U. (1990). Inorganic sediment chemistry and elemental speciation. In Baudo, R., Giesy, J., \& Muntau, H. (Eds.), Sediments: Chemistry and Toxicity of In-Place Pollutants (pp. 61-97). CRC Press Inc, Boca Raton, FL.

Förstner, U., \& Wittman, G. T. W. (1983). Metal Pollution in Aquatic Environment. Springer Verlag, New York.

González, M. C., Méndez, L., López, D., \& Botello, A. (2006). Evaluación de la contaminación en sedimentos del área portuaria y zona costera de Salina Cruz, Oaxaca, México. Interciencia, 31, 647-656.

Håkanson, L. (1980). An ecological risk index for aquatic pollution control of sediment ecological approach. Water Research, 14, 975-1000. https://doi.org/10.1016/0043-1354(80)90143-8

Hammer, Ø., Harper, D. A. T., \& Ryan, P. D. (2001). PAST: paleontological statistics software package for education and data analysis. Palaeontol. Electron.

Harte, J., Holdren, C., Schneider, R., \& Shirley, C. (1991). Toxics A to Z, a guide to everyday pollution hazards. University of California Press, Oxford, England, pp. 478.

Hilton, J., Davison, W., \& Ochsenbein, U. (1985). A mathematical model for analysis of sediment coke data. Chemical Geology, 48,281-291. https://doi.org/10.1016/0009-2541(85)90053-1

Hottin, G., \& Ouedraogo, O. F. (1972). Carte géologique du Burkina Faso 111000000. Notice explicative. 
Bureau des mines et de la géologie du Burkina.

Ibrahim, B., Polcher, J., Karambiri, H., \& Rockel, B. (2012). Characterization of the rainy season in Burkina Faso and its representation by regional climate models. Climate Dynamics, 39, 1287-01302. https://doi.org/10.1007/s00382-011-1276-X

INSD (Institut National de la Statistique et de la Démographie). (2000). Analyse des résultats du Recensement Général de la Population et de l'Habitation de 1996. Volume 1. Ouagadougou: INSD, 348p.

INSD (Institut National de la Statistique et de la Démographie). (2011). Ki, F, Ndanga-Kouali, G, Tankoano JP (2010). Étude diagnostique de la gestion du barrage de Mogtédo. Report prepared for the WAIPRO project. Ouagadougou, Burkina Faso: IWMI.

Kabata-Pendias, A. (2011). Trace elements in soils and plants (4th ed.). CRC Press, Boca Raton FL. 520 p.

Kelderman, P., \& Osman, A. (2007). Effect of redox potential on heavy metal binding forms in polluted canal sediments in Delft (The Netherlands). Water Research, 41, 4251-4261. https://doi.org/10.1016/j.watres.2007.05.058.

Leboulanger, C., Bouvy, M., Pagano, M., Dufour, R. A., Got, P., \& Cecchi, P. (2009). Responses of Planktonic Microorganisms from Tropical Reservoirs to Paraquat and Deltamethrin Exposure. Archives of Environmental Contamination and Toxicology, 56(1), 39-51. https://doi.org/10.1007/s00244-008-9164-z

Mackay, D. (2001). Multimedia environmental models: the fugacity approach (2nd ed.). CRC Press, USA 39-44.

Macklin, M. G., Brewer, P. A., Hudson-Edwards, K. A., Bird, G., Coulthard, T. J., Dennis, I. A. ... Turner, J. N. (2006). A geomorphological approach to the management of rivers contaminated by metal mining. Geomorphology, 79, 423-447. https://doi.org/10.1016/j.geomorph.2006.06.024

Mahé, G., \& Paturel, J. E. (2009). 1896-2006 Sahelian annual rainfall variability and runoff increase of Sahelian Rivers. Comptes rendus Geoscience, 341,538-546. https://doi.org/10.1016/j.crte.2009.05.002

Martin, C. W. (2000). Heavy metal trends in floodplain sediments and valley fill, River Lahn, Germany. Catena, 39, 53-68. https://doi.org/10.1016/S0341-8162(99)00080-6

McBride, M. B. (1994). Environmental Chemistry in Soils. Oxford University Press, Oxford.

Morin, D. (1990). Contribution à l'amélioration de l'intervention en aménagement hydroagricole: Cadre de référence en santé communautaire. Mémoires et Thèses, $\mathrm{N}^{\circ} 3$, Université Laval, Québec, 43p.

Muñoz-Barbosa, A., Gutiérrez-Galindo, E. A., Daesslé, L. W., Orozco-Borbón, M. V., \& Segovia-Zavala, J. A. (2012). Relationship between metal enrichments and a biological adverse effects index in sediments from Todos Santos Bay, northwest coast of Baja California, México. Marine Pollution Bulletin, 64, 405-409. https://doi.org/10.1016/j.marpolbul.2011.11.023

Muñoz-Olivas, R., \& Cámara, C. (2001). Speciation related to human health. In L. Ebdon, L. Pitts, R. Cornelis, H. Crews, O. F. X. Donard, \& P. Quevauviller (Eds.), Trace element speciation for environment, food and health (pp. 331-353).

Nelson, D. W., \& Sommers, L. E. (1992). Total carbon, organic matter. In Page, A. L., Miller, R. H., \& Keamey, D. R. (Eds.), Methods of Soil Analysis. Part 2, Chemical and Microbiological Properties. American Society of Agronomy (pp. 539-579). Inc., Madison, USA.

Nouri, J., Mahvi, A. H., Jahed, G. R., \& Babaei, A. A. (2008). Regional distribution pattern of groundwater heavy metals resulting from agricultural activities. Environmental Geology, 55, 1337-1343. https://doi.org/10.1007/s00254-007-1081-3

Nüremberg, H. W. (1984). The voltammetric approach in trace metal chemistry of natural waters and atmospheric precipitation. Analytica Chimica Acta, 164,1-21. https://doi.org/10.1016/S00032670(00)85613-5

Pleysier, J. L., \& Juo, A. S. R. (1980). A single-extraction method using silver-thiourea for Measuring exchangeable cations and effective CEC in soils with variable charges. Soil Science, 129(4), 205-211. https://doi.org/10.1097/00010694-198004000-00002

Poda, J. N. (1996). Distribution spatiale des hôtes intermédiaires des schistosomes au Burkina Faso: Facteurs influençant la dynamique des populations de Bulinus truncatus rohlfsi CLESSIN, 1886 et de Bulinus senegalensis MULLER, 1781. Thèse de doctorat FAST. Ouagadougou, Burkina Faso 215p.

Poda, J. N., \& Traoré, A. (2000). Situation des schistosomoses au Burkina Fason. In: La luttecontre les 
schistosomoses en Afrique de l'Ouest, ed. Chippaux, J.-P. Communications présentées à l'atelier sur les difficultés rencontrées dans la mise en oeuvre des programmes de lutte contre les schistosomoses en Afrique de l'Ouest, Niamey-Cermes, 15-18 février 2000. Paris: IRD Éditions, Institut de Recherche pour le Développement, Collection Colloques et Séminaires, pp. 177-195.

Reza, R., \& Singh, G. (2010). Heavy metal contamination and its indexing approach for river water. International Journal of Environmental Science and Technology, 7, 785-792. https://doi.org/10.1007/BF03326187

Rosen, M. R. (2015). The influence of hydrology on lacustrine sediment contaminant records. In Blais et al. (Eds.), Environmental contaminants, Developments in Paleoenvironmental Research, 18, 1-11. https://doi.org/10.1007/978-94-017-9541-8_2

Rouiller, J., Souchier, B., Bruckert, S., Feller, C., Toutain, F., \& Védy, J. C. (1994). Méthode d'analyses des sols. In Bonneau M., \& Souchier B. (Eds.), Pédologie 2. Constituants et propriétés du sol (pp. 619-52). Paris: Masson.

Saeedi, M., Li, L. Y., Karbassi, A. R., \& Zanjani, A. J. (2013). Sorbed metals fractionation and Assessment of release in river sediment and particulate matter. Environmental Monitoring and Assessment, 185, 1737-1754. https://doi.org/10.1007/s10661-012-2664-3

Sandstead, H. H. (1995). Is zinc deficiency a public health problem? Nutrition, 11, 87-92.

Savy, M., Martin-Prével, Y., Traissac, P., Eymard-Duvernay, S., \& Delpeuch, F. (2006). Dietary diversity scores and nutritional status of women change during the seasonal food shortage in rural Burkina Faso. J. Nutrition, 136, 2625-2632. https://doi.org/10.1093/jn/136.10.2625

Suresh, G., Ramasamy, V., Meenakshisundaram, V., Venkatachalapathy, R., \& Ponnusamy, V. (2011). Influence of mineralogical and heavy metal composition on natural radionuclide contents in the river sediments. Applied Radiation and Isotopes, 69, 1466-1474. https://doi/org./10.1016/j.apradiso.2011.05.020

Sutherland, R. A., \& Tack, F. M. G. (2002). Determination of Al, Cu, Fe, Mn, Pb and $\mathrm{Zn}$ in certified reference materials using the optimized BCR sequential extraction procedure. Analytica Chimica Acta, 454, 249-257. https://doi.org/10.1016/S0003-2670(01)01553-7

Venot, J. P., \& Cecchi, P. (2011). Valeurs d'usage ou performances techniques: Comment apprécier le rôle des petits barrages en Afrique subsaharienne. Les Cahiers de l'Agriculture, 20(1-2), 112-117. https://doi.org/10.1684/agr.2010.0457

Vincent, L. (1994). Lost chances and new futures: Interventions and institutions in small-scale irrigation. Land Use Policy, 11(4), 309-22. https://doi.org/10.1016/0264-8377(94)90056-6

Violante, A., Cozzolino, V., Perelomov, L., Caporale, A. G., \& Pigna, M. (2010). Mobility and bioavailability of heavy metals and metalloids in soil environments. Journal of Soil Science and Plant Nutrition, 10(3), 268-292. http://dx.doi.org/10.4067/S0718-95162010000100005

Wang, Y., Yang, Z., Shen, Z., Tang, Z., Niu, J., \& Gao, F. (2011). Assessment of heavy metals in sediments from a typical catchment of the Yangtze River, China. Environmental Monitoring and Assessment, 172, 407-417. https://doi.org/10.1007/s10661-010-1343-5

Yi, Y., Yang, Z., \& Zhang, S. (2011). Ecological risk assessment of heavy metals in sediment and human health risk assessment of heavy metals in fishes in the middle and lower reaches of the Yangtze River basin. Environmental Pollution, 159, 2575-2585. https://doi.org/10.1016/j.envpol.2011.06.011

Zeng, H., \& Wu. J. (2013). Heavy metal pollution of lakes along the mid-lower reaches of the Yangtze River in China: intensity, sources and spatial patterns. International Journal of Environmental Research and Public Health, 10, 793-807. https://doi.org/10.3390/ijerph10030793

Zhang, C., Yu, Z., Zeng, G., Jiang, M., Yang, Z., Cui, F., Zhu, M., Shen, L., \& Hu, L. (2014). Effect of sediment geochemical properties on heavy metal bioavailability. Environment International, 73, 270-281. https://doi.org/10.1016/j.envint.2014.08.010

\section{Copyrights}

Copyright for this article is retained by the author(s), with first publication rights granted to the journal.

This is an open-access article distributed under the terms and conditions of the Creative Commons Attribution license (http://creativecommons.org/licenses/by/4.0/). 